\title{
Implementation Of Team Game Tournament Model To Improve Student Learning Results On Fraction
}

\section{T Tarusu ${ }^{1}$}

${ }^{1}$ Universitas Negeri Manado, Indonesia

corresponding author: deystitarusu@unima.ac.id

\begin{abstract}
This study aims to improve the learning outcomes of mathematics in elementary school, especially in fraction material by applying the Team Game Tournament (TGT) learning model. This study uses the Classroom Action Research (CAR) method which refers to the opinion of Kemmis and Mc Taggart with 4 stages: planning, action, observation, and reflection. The subjects of this study were the fifth grade students of GMIM I Tomohon Elementary School totaling 15 students. This research was conducted in two cycles. The results obtained in the first cycle reached $46.67 \%$, while in the second cycle it reached $86.67 \%$. Thus it can be concluded that by applying the Team Game Tournament (TGT) model can improve student learning outcomes, especially in fraction addition and subtraction count operations in class V of GMIM I Tomohon Elementary School
\end{abstract}

Keywords: Team Game Tournament Model, Learning Outcomes, Fractions

\section{Introduction}

Various efforts have been made by the government to improve the quality of education in Indonesia, such as improving the curriculum, training teachers and providing adequate facilities and infrastructure. In Law No. 14 of 2005, concerning Teachers and Lecturers, the government pays attention to educators by stipulating that it is necessary to conduct teacher certification for teaching staff in the framework of professional teachers.

As a professional, teachers are required to have a teaching ability that is displayed in the form of skills. In teaching and learning activities teachers are required to carry out effectively and efficiently because improving the quality of education is not enough just by the efforts of the teacher in giving lessons to students but the activities and active roles of students are also very decisive towards the ignition of student learning outcomes. Many challenges or difficulties that must be faced by teachers in the teaching and learning process in the classroom to achieve quality and quality education especially teaching teachers at the elementary school level.

Education in elementary school aims to provide basic skills and abilities, namely "read-write-count", and basic skills that benefit students according to their level of development and prepare them for higher level education. 
The primary school curriculum in both the 2013 KTSP and curriculum, especially for mathematics subjects includes competencies that require students to understand arithmetic operations about fractions. Here the teacher is required to have an important role and determine the success of student learning in school. Therefore, the teacher must carry out their duties and functions and try to implement various ways or strategies in order to achieve a goal in learning.

Based on observations in Mathematics learning, especially in counting operations and subtraction fractions in class V of SD GMIM I Tomohon that completing ordinary fractions has not been well implemented because students in solving fractions have not yet understood how to solve them using a formula that matches the problem, how involves the reduction, division and multiplication in the problem.

Of the 15 students who were able to achieve the KKM score only 5 students, while 10 students needed to improve their learning outcomes. If presented, the number reaching KKM only reached $33.33 \%$. These learning outcomes are seen in the final test conducted by students during the implementation of learning. In the implementation of classroom learning the teacher does not involve students, so students only play and are not focused on participating in the learning process activities and especially in fractional counting operations students have not been able to solve how to solve problems using formulas according to the character of the questions. To solve this problem, the teacher must be able to use learning methods and models that are in accordance with the character of the students and the material to be taught.

According to Agus Suprijono (2010: 64) the learning model is a pattern that is used as a guide in planning classroom learning and tutorials.

According to Arends (Trianto, 2009: 41), the learning model is a learning model specifically designed to support student learning processes related to declarative knowledge and well-structured procedural knowledge, can be taught with a pattern of activities that are step by step.

One learning model that can make students participate actively in the learning process in the classroom, especially in learning material about fractional counting operations is the Team Game Tournament (TGT) learning model.

The steps that can be taken in applying the Team Game Tournament model according to Salvin (Rusman, 2014: 225) are as follows:

1) Class Presentation

This presentation can be either direct learning or a lecture performed by the teacher, but can include audio-visual presentations.

2) Team

The team usually consists of 5-6 heterogeneous members seen from the academic percentage, gender, ethnicity. The team's function is to explore the material with the team and more that works well and optimally during the game.

3) Game

Consists of questions that are designed to test students' knowledge obtained from class percentages and learning in teams

4) Tournaments 
Usually tournaments are conducted at the end of the lesson after the teacher has done the class percentage and the team after working on the student worksheet

5) Group awards

The teacher then announces the winning group, each team group will get a prize if they meet the average score and meet the specified criteria.

Based on the description above, in this study the authors are interested in conducting research by applying the Model Team Game Tournament (TGT) to improve Mathematics Learning Outcomes of fifth grade students of SD GMIM I Tomohon.

The formulation of the problem in this study is whether the Application of the Model Team Game Tournament (TGT) can improve the Mathematics Learning Outcomes of Grade V Students of SD GMIM I Tomohon?

This study aims to improve the learning outcomes of mathematics in elementary school especially in fractions by applying the Team Game Tournament (TGT) learning model.

This research can be useful (1) for teachers as input to understand, implement and implement the Team Game Tournament (TGT) model to improve student learning outcomes; (2) for students to be more active in learning activities and can understand the material taught especially material on addition and subtraction of fractions by applying the Team Game Tournament (TGT) learning model; (3) for schools as a consideration for elementary school teachers to be able to design a Team Game Tournament (TGT) learning model that can improve the quality of education.

\section{Methods}

This research uses Classroom Action Research (CAR) method with reference to the opinion of Kemmis and Mc Taggart (in Agib Zainal, 2006: 31), In this study following the steps as follows: (a) planning, (b) action, (c) observation , and (d) reflection. The flow of this research can be seen in the picture as follows:

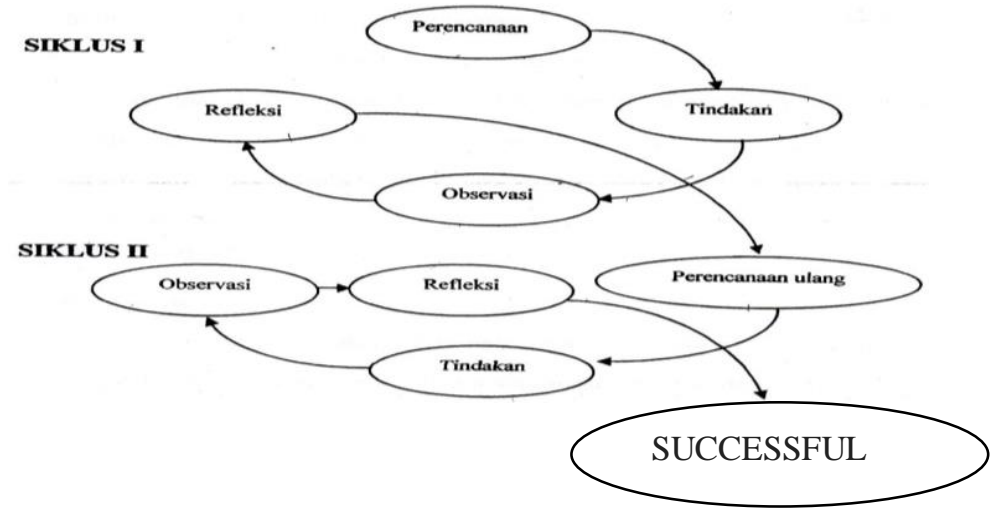

Figure 1. Classroom Action Research Flow

The research subjects were fifth grade students of SD GMIM I Tomohon, with 15 students consisting of 7 men and 8 women. 
The research procedure in this study consists of planning, action, observation, and reflection. Data collection techniques in this study include observation and tests.

Observation, namely observation of objects by the way researchers obtain data objectively, to monitor the activity of each student during learning, researchers are assisted by class teachers (colleagues) in observing, recording events during the learning activities taking place

The test, is used to see the results achieved by students after following the learning process. In this study the test used is a written test in the form of a question test.

The data analysis technique in this study uses the classical mastery learning formula:

$$
\mathrm{KB}=\frac{T}{T t} \times 100 \%
$$

Information :

$\mathrm{KB}=$ Learning completeness

$\mathrm{T}=$ Number of students completed $/ \mathrm{KKM}$

$\mathrm{Tt}=$ Number of students taking the test

(Komara et al. 2016: 163)

Each student is said to have completed his study (individual completeness) if he reaches the KKM value $\geq 75$ according to the KKM determined by the school. A class is said to be complete (classical completeness) if $\geq 85 \%$ have reached KKM.

\section{Results and Discussions Research findings \\ Cycle I}

At this stage, what the researcher does is take material that is in accordance with the Education Unit Level curriculum, then prepare a lesson plan complete with the learning scenario that has been adapted to the Game Tournament Team learning model that has been used. In the preparation of this RPP, there is cooperation with agreements between researchers, class teachers and principals so that the teaching and learning process can be well coordinated. Besides that, it also supports learning design prepared aids in learning, both teaching aids and evaluation tools, in addition there are also assessment instruments prepared to record various events that occur during the teaching and learning process takes place.

Student learning outcomes can be seen from the evaluation sheet carried out by students to measure the extent to which student learning achievement increases, as well as the success and achievement of research objectives.

\section{Cycle I Test Results}

$\mathrm{KB}=\frac{T}{T t} \times 100 \%$ 
$\mathrm{KB}=\frac{7}{15} \times 100 \%=46,67 \%$

\section{Cycle II}

In this second cycle there was no change in material or learning model used, but in this cycle it was focused on improving each deficiency in Cycle I.

Each student is said to be complete if he can answer the 5 questions given, from the results of tests given by the teacher, according to the KKM determined by the school. A class is said to be complete (Classical completeness) if in a class there are $85 \%$ who have reached KKM.

\section{Cycle II Test Results}

$$
\begin{aligned}
\mathrm{KB} & =\frac{T}{T t} \times 100 \% \\
\mathrm{~KB} & =\frac{13}{15} \times 100 \%=86,67 \%
\end{aligned}
$$

\section{Discussion}

The discussion of the results of this study is based on the results of student learning tests which are followed by reflection on observations in each cycle of action.

The fact shows that students are still rigid with the learning model carried out by the teacher so that they are still having difficulty in understanding mathematical concepts, especially counting operations and subtraction of fractions in class V SD GMIM I Tomohon which results in learning outcomes in the first cycle, out of 15 students there were only 7 students who reached $\mathrm{KKM} \geq 75,8$ students had not yet reached KKM, so the success of cycle 1 only reached $46.67 \%$ and could not be successful. All deficiencies that exist in this first cycle are corrected in the second cycle.

In the second cycle of learning implementation researchers are more focused in mastering the implementation of the steps of the learning model and through these steps the researcher can explain how to solve fraction problems using formulas, and also students are directly involved in demonstrating the problem of fractions, they are also getting used to and liked the model of learning carried out by the teacher. Thus directly students become creative and active in participating in learning activities. The success achieved in the implementation of the second cycle of the number of 15 students was found only 2 students who did not meet the maximum score completeness, and 13 students had fulfilled the maximum value completeness, so the success rate in the second cycle reached $86.67 \%$ and stated action on second cycle succeed. In other words, there is an increase in learning outcomes from the first cycle in the second cycle by $40 \%$.

\section{Conclusions}

Based on the results of the research and discussion that has been described, it can be concluded that: The application of the Team Game Tournament (TGT) model can improve the mathematics learning outcomes of fifth grade students of SD GMIM I Tomohon. 
Based on the conclusions of the research results, the following matters can be suggested:

1. It is expected that grade V teachers can apply the Team Game Tournament model in mathematics learning, especially in fraction addition and subtraction material.

2. In applying the Game Tournament Team model, it is necessary to pay attention to the learning steps (1) class percentage, (2) team formation, (3) games, (4) tournaments, and (5) group awards.

3. It is expected that students as prospective teachers can improve the quality and cognitive and psychomotor abilities to be able to create fun learning for students.

\section{References}

Anuhraman. 2009. Learning and Learning. Bandung. Alfabeta.

Darhim et al. 1991 Mathematics Education 2. Department of Education and Culture: Jakarta

Ministry of National Education.2005. Law Number 14, concerning Teachers and Lecturers

Isjoni. 2011. Cooperative Learning Effectiveness of Group Learning. Bandung: ALFABETA.

Komara, Endang, et al.2016. Sustainable Professional Development in classroom action research for teachers. Bandung: Refika Aditana.

Kunandar. 2011. Easy Steps for Class Action Research as Teacher Professional Development. Jakarta: Rajagrafindo Persada.

Muhsetyo, G. 2007. Elementary Mathematics Learning. Jakarta: Open university

Mulia,F. 2013. What Is Mathematics? .Http: //dedi26.Blogspot.com (accessed July 26, 2014)

Rusman, 2014. Learning Models. PT. Raja Grafindo Persada

Trianto. 2009. Designing Progressive Innovative Learning Models Concepts, Platforms and Implementation in KTSP. Kencana

Zinal, Aqib. 2006. Classroom Action Research. Contents: YramaWidya 